\title{
温度センシング用シリカトロイド微小光共振器の実装技術
}

\author{
小林 美紗子, 西村 治郎, 田邊 孝純 \\ 慶應義塾大学 理工学部電子工学科 ( ₹223-8522 神奈川県横浜市港北区日吉3-14-1)
}

\section{Packaging Technology of a Silica Toroidal Optical Microcavity for Temperature Sensing}

\author{
Misako KOBAYASHI, Jiro NISHIMURA, and Takasumi TANABE \\ Department of Electronics and Electrical Engineering, Faculty of Science and Technology, Keio University, \\ Yokohama, Kanagawa, 223-8522, Japan
}

(Received October 1, 2015)

\begin{abstract}
Silica toroid microcavities is an ideal platform if we want to obtain high sensitivity and small device size simultaneously. However, it requires precise alignment of a tapered optical fiber in order to couple light into the microcavity. In this study we report on the packaging of a silica toroidal microcavity with an input-output tapered optical fiber, which enable us to make this device portable and use for practical applications. The obtained $Q$ of the packaged device is $1.7 \times 10^{6}$, and we performed thermal sensing by using this device.
\end{abstract}

Key Words: Microcavity, Optofluidics, Optical sensor, Tapaerd nano-fiber, Packaging

\section{1. はじめに}

微小光共振器は光を非常に小さな領域に高い密度で長 時間閉じ込めることが可能な素子である，光を用いた各 種センサ(温度センサや化学物質センサ)は幅広い分野で の利用が期待されており, それらは物質の複素誘電率 (屈折率や吸収)の変化に由来する光の変化を検出するこ とで動作する。特に，可燃性・支燃性物質の検出には， 着火の恐れがあるような電気で駆動する検出器を用いる のは好ましくなく, 光によるセンサの活躍が期待され る.

しかし, 一般的に光と物質の電気双極子との相互作用 は小さいため, 高い感度を得るには光と検出媒質との相 互作用長を大きくする必要があり，その結果素子が大き くなってしまうという問題がある。したがって一般的に 素子サイズと感度にはトレードオフが存在する。一方で 微小光共振器を用いれば，光を長く閉じ込めることがで きるので, 小型なデバイスでも高感度なセンシングがで きると期待されている。 その中でもWGM(Whispering Gallery Mode) 共振器の1つであるシリカトロイド共振器 が近年特に注目を集めている ${ }^{1)}$. シリカトロイド共振器 は $10^{8}$ オーダー以上の高 $Q$ 值が見达めるうえ, $\mathrm{Si}_{-}-\mathrm{SiO}_{2}$ と いう単一材料から作製可能であるため集積化に向いてい るという利点がある。

シリカトロイド共振器を用いることで, 光コム発生 ${ }^{2)}$ や高感度センシング3-8) などの応用が可能となる. 特に WGM共振器による高感度センシングは2000年代前半か ら盛んになってきた研究であり，重水検出 ${ }^{3)}$ や温度セン
$サ^{4)}$, タンパク質の検出 ${ }^{5)}$, 単一ナノ粒子 ${ }^{6)}$ やインフルエ ンザAウイルス ${ }^{7)}$ の検出, 揮発性有機化合物の検出と同 定 ${ }^{8)}$ な゙が行われている.

WGM共振器をセンシングに用いる際には，直径数 100 $\mathrm{nm}$ となるように延伸させたテーパナノファイバを用い てWGM共振モードを励起させる，高効率に結合させる ためには，共振器中を周回する光の伝搬速度と，ナノ ファイバ中を伝搬する速度を整合する必要がある。特 に，エバネッセント波を介して結合させるので，テーパ ファイバの位置をWGM共振器の側面に精密にアライメ ントする必要があり, 実験室外に持ち出すのは容易では ない.

その課題を解決すため, 我々はWGM共振器の形状を 制御することで，安定的な結合を実現する手法を開発し たが9,10)，その一方で, WGM共振器にテーパファイバを 固定してパッケージングする報告もなされている ${ }^{11,12)}$. しかしこれらの手法ではWGM共振器に紫外線 (Ultra Violet: UV) 硬化性樹脂を付着させるため, 光コム発生やセ ンシングなどの応用には向かないという問題点がある.

本報告では, シリカトロイド共振器に直接UV硬化性 樹脂を付着させずにパッケージングする手法を検討し, 評価した。また，作製した素子を用いて温度センシング のデモンストレーションを行った.

\section{2. パッケージング手法の検討}

先述のように，現在報告されているパッケージング手 法はWGM共振器にUV硬化性樹脂を付着させるため応用 
が限られる。ささらに， $\mathrm{SiO}_{2}$ の屈折率は 1.45 程度であり， 低屈折UV硬化性樹脂を用いなければ光が共振器の外に 漏れ出てしまう。そのため, これらの報告では屈折率が 1.3 程度のUV硬化性樹脂を用いているが, これの硬度は 低く安定性が低いと考えられる。そこで，本報告では屈 折率が1.6程度だが，高い硬度を得られるUV硬化性樹脂 を用いてFig. 1のような手順でパッケージングを行った 素子の両側に $0.1 \mathrm{~mL}$ 程度のUV硬化性樹脂を液滴し, そ の状態で微小共振器素子を調芯装置にセットアップし た。次に, 調芯装置に固定されたテーパファイバとの精 密な位置アライメントを行う。その後光学測定を行い, 適切に透過スペクトルが測定できる位置を確認する。 UV光を照射するとUV硬化性樹脂が収縮するので, テー パファイバの位置がずれることを防止することや，パッ ケージング後の素子の強度安定性をより高めることを目 的として, Fig. 2のようにシリカトロイド共振器の左右 に300 $\mu \mathrm{m}$ の幅の台を付ける構造のものを作製した。こ の台はシリカトロイド共振器を作製するのと同様にフォ トリソグラフィにより作製している。 シリカトロイド共 振器の作製時には $\mathrm{CO}_{2}$ レーザーリフローを行うが, 台に 対してはリフローを行わないことでテーパファイバの位 置アライメントに適した高さにすることができる。しか し実際には，それでもUV硬化性樹脂を硬化させると数 $\mu \mathrm{m}$ 程度の移動が生じるため, あらかじめその変化分を 見越してテーパファイバの位置をずらしておく，その状 態のままUVランプを照射しUV硬化性樹脂を硬化させて テーパファイバと微小光共振器の位置を固定化させる. 最後に，テーパファイバを調芯装置から取りはずす.

(a)

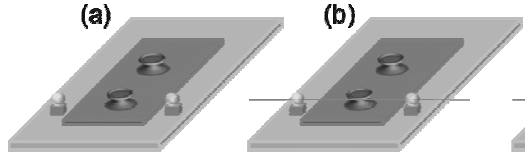

Fig. 1 Schematic illustration of the procedure of silica toroid microcavity packaging. A small drops of UV curable polymer are placed on both side of a cavity (a). Tapered nano-fiber is aligned in order to couple light with a silica toroid microcavity (b). UV light is exposed for about 30 minutes (c).

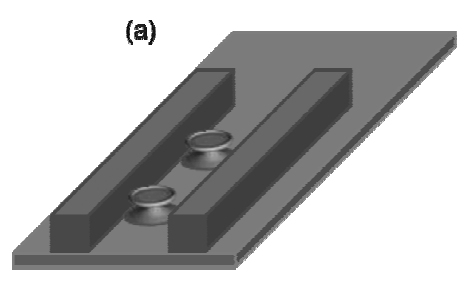

(b)

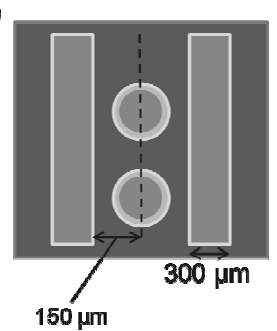

Fig. 2 (a) Schematic illustration of a silica toroid microcavities with tables for fiber holding. (b) Illustration from the top of the chip.

\section{3. パッケージングされた共振器の評価}

\section{$3.1 Q$ 值測定}

Fig. 1に示した手順でパッケージングを行いケースに 収めた状態の素子の写真と電子顕微鏡 (Scanning electron microscope: SEM) 画像をそれぞれFig. 3 (a) と (b)に示す. 今回は沉用ケースを用いたため $40 \times 30 \times 55 \mathrm{~mm}^{3}$ のケー スに収納したが，チップサイズは $5 \mathrm{~mm}^{2}$ 以下であるの で，本質的にパッケージングした素子サイズはmmオー ダーもあれば十分である。テーパファイバの両端はシン グルモードファイバである。 パッケージングを実現した ことによって，素子への入出力は直接シングルモード ファイバを介して高効率に行えるようになった。 このこ とが本研究において重要な点であり, 強調したい成果で ある。

UV光照射前後とテーパファイバを調芯装置から取り 外した後の透過スペクトルをFig. 4に示す. Fig. 3 と Fig. 4 より，持ち運びが可能なサイズの箱にパッケージングで き，パッケージングされた状態で $Q=1.7 \times 10^{6}$ を達成で きたことがわかった。

UV光照射によりUV硬化性樹脂が収縮することを考慮 してUV光照射前のアライメントを行ったため, Fig. 4 (a)のUV光照射前の透過スペクトルには共振が見られな いが，UV光照射後には共振が見られる。パッケージン グ後には，ほぼ全ての素子で共振スペクトルが得られる が，これもシリカトロイド共振器の左右に付けた台によ

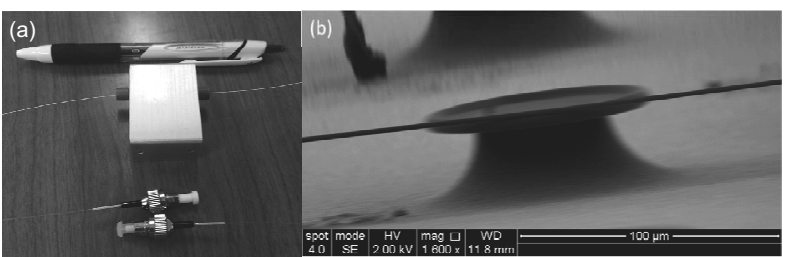

Fig. 3 (a) Photograph of the packaged device installed in a metal case connected with input and output fibers. The device is fabricated with a process shown in Fig. 1. (b) SEM image of a packaged cavity with tapered nano-fiber.

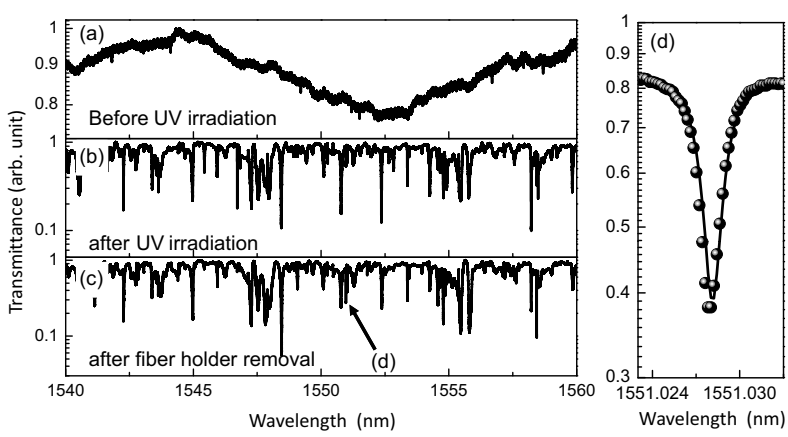

Fig. 4 Transmittance spectra of the device, before UV light exposure (a), after UV light exposure (b), and after it is removed from the tapered fiber alignment system (c). The magnified transmittance spectrum of one of the resonance (d). 
り位置ずれが抑えられるようになったためである.

また，UV光照射後とテーパファイバを調芯装置から 取り外した後の透過スペクトルにおいて多数のモードが 存在しているのは, シリカトロイド共振器とテーパファ イバがFig. 3（b)で観測されたように側壁に接している ため, over couplingの状態であるからである。

\section{2 安定性の評価}

次に，作製した共振器のパッケージングの実用性につ いて調べるために，作製してからの経過時間と振動の影 響について評価した。

まず，作製してからの経過時間に対する安定性につい て評価を行った。1つのデバイスを作製直後，作製して から3日後，14日後に透過スペクトルを測定した. Fig. 5 にその結果を示し，それぞれの透過スペクトルより得ら れた $Q$ 值の変化をTable. 1 に示す. 通常我々が $Q$ 值と呼ぶ のは，透過スペクトルより得られる $Q_{\text {load }}$ のことを指す。 一方で, 共振器の性能を議論するためには, 共振器の固 有 $Q$ 值 $Q_{\text {int }}$ と結合 $Q$ 值 $Q_{\text {couple, }}$ を分けて考えなくてはなら
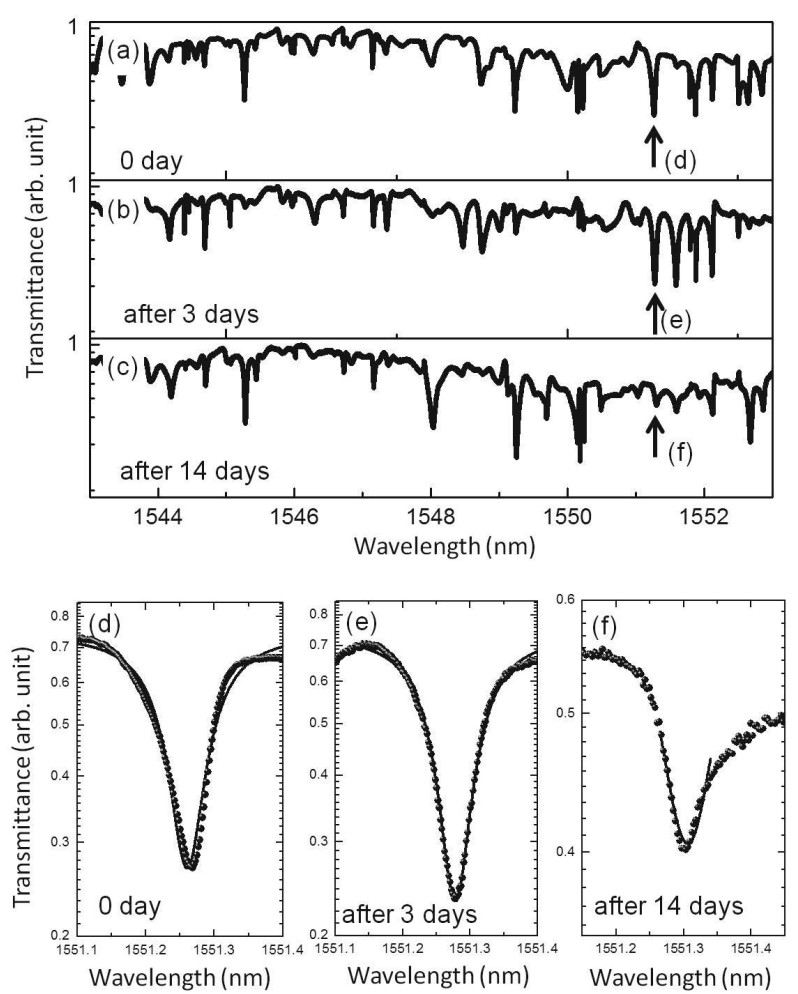

Fig. 5 Measured transmittance spectra of 0,3 , and 14 days after the fabrication of the packaged device (a-c). (d-f) are the magnified transmittance spectrum of one of the resonant mode. The $Q$ of this mode has changed from (d) $9.9 \times 10^{5}$, (e) $9.8 \times$ $10^{5}$, to (f) $4.6 \times 10^{5}$.

Table $1 Q$ s of 0,3 , and 14 days after the fabrication of the packaged device

\begin{tabular}{cccc}
\hline days & $\boldsymbol{Q}_{\text {load }}$ & $\boldsymbol{Q}_{\text {int }}$ & $\boldsymbol{Q}_{\text {couple }}$ \\
0 & $9.9 \times 10^{5}$ & $2.0 \times 10^{6}$ & $2.0 \times 10^{6}$ \\
3 & $9.8 \times 10^{5}$ & $1.9 \times 10^{6}$ & $2.0 \times 10^{6}$ \\
14 & $4.6 \times 10^{5}$ & $8.3 \times 10^{5}$ & $1.0 \times 10^{6}$ \\
\hline
\end{tabular}

ない. $Q_{\text {load }}$ と透過率Tの関係は

$$
\begin{aligned}
& Q_{\text {couple }}=\frac{Q_{\text {load }}}{\sqrt{T}} \\
& \frac{1}{Q_{\text {load }}}=\frac{1}{Q_{\text {int }}}+\frac{1}{Q_{\text {couple }}}
\end{aligned}
$$

となることから，作製直後，作製してから3日後，14日 後の共振器の $Q_{\text {int }}$ と $Q_{\text {couple }}$ を求めることができる。 その結 果, $Q_{\text {int }}$ 方が $Q_{\text {couple }}$ より大きな割合で低下していた。 テーパファイバと共振器の位置関係がずれると $Q_{\text {couple }}$ に 影響を与えるため, パッケージングは十分に安定してい ると言える。一方で， $Q_{\text {int }}$ は共振器に埃や $\mathrm{OH}^{-}$基などが 付着することによって低下することから，パッケージン グされた共振器を真空中など埃や $\mathrm{OH}^{-}$基の少ないところ に保存することでより長い期間, 性能を保持できると考 えられる。

次に, 共振状態にあるシリカトロイド共振器とテーパ ファイバの真上から中心周波数 $40 \mathrm{kHz} \pm 1 \mathrm{kHz}$ の超音波 スピーカを近づけることで振動に対する安定性を調べ た。この周波数帯の音波は空気中の減衰が比較的小さく $1 \mathrm{~dB} / \mathrm{m}$ 程度であり, 距離計測等の様々な機器に用いられ ている.

テーパファイバが摇らぎ, 光が共振器に結合する強度 が変化すれば，その振動周波数に対応する光強度変調が 観測されるはずである。そこで，透過光強度をフォトダ イオードで観測し電気スペクトルアナライザで測定して 評価した。 その結果をFig. 6に示す。振動を与えない環 境で透過スペクトルを測定すると，パッケージングした 素子は透過光強度の摇らぎが低減している。特に, $100 \mathrm{MHz}$ 以下の周波数において低減の効果が顕著に表れ ている。 パッケージングした素子においては，テーパ光 ファイバと共振器の表面がしっかりと接触していると考 えられ, 共振器やテーパ光ファイバの機械的な振動が光 結合に与える影響が抑えられると予想できる。使用して いるトロイド共振器の機械的な固有振動数はおおよそ $50 \mathrm{MHz}$ 付近に存在することからも, パッケージングの 有効性が示されているといえる。

超音波スピーカで振動を与えると, パッケージングの 有無にかかわらず，振動の影響は観測されるものの， Fig. 6(b)に示すようにその影響はパッケージングによっ て低減されていることがわかる，MHzを超える高周波 数に観測される理由ははっきりとはわからないものの, 観測結果として470 MHz付近の振動が低減されている. 振動の影響が軽減された理由は，直観的にはファイバの 固定端の間の距離が著しく近くなったからだと考えられ る。パッケージングしていない状態ではテーパファイバ の固定位置間の距離は治具の制約をうけて7 cm程度とな るが, パッケージングすればその距離は $1 \mathrm{~cm}$ 未満であ る。さらにフォトリソグラフィで作製した固定台が共振 器素子の両側に配置されているため, 実効的な距離はさ らに短い.

簡単のためにファイバを両端が固定された梁として考 えると振動のエネルギー $\varepsilon$ は, $\alpha$ を定数, $c$ を振幅, $R$ を 
(a)

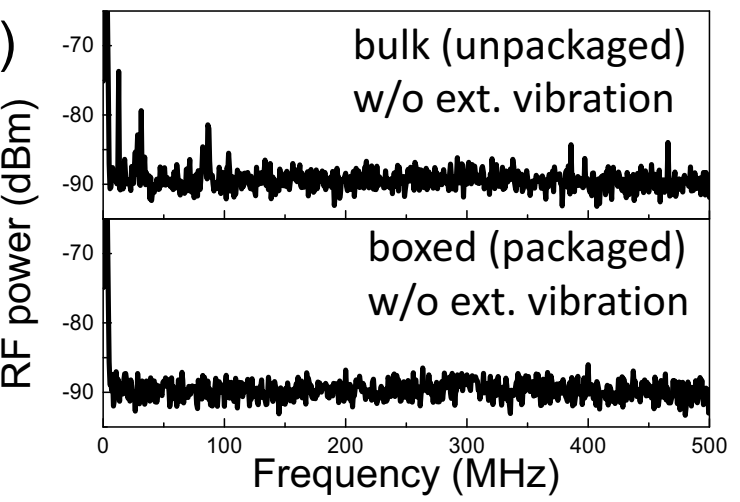

(b)

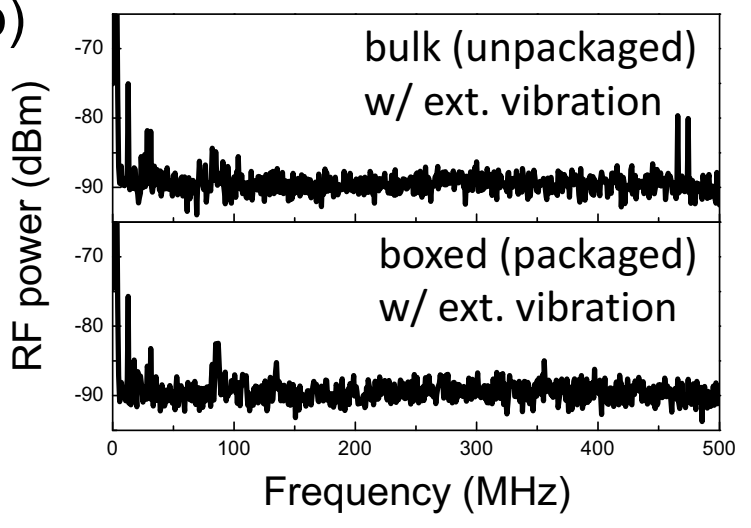

Fig. 6 Effect of the vibration. The radio-frequency of the transmitted intensity of the continues-wave light at the cavity resonance of the packaged and unpackaged cavities without (a) and with external vibration (b).

ファイバ半径, $E$ をヤング率， $l$ 固定端間の距離として

$$
\varepsilon=\alpha \cdot \frac{c^{2} R^{2} E}{l^{2}}
$$

と表すことができる，先述したようにパッケージングさ れている場合のlは $1 \mathrm{~cm}$ 不，パッケージングされてい ない場合のlは7 cm程度であるので, (2)より振動のエネ ルギーを一定として $c$ を計算するとパッケージングされ ている場合はパッケージングされていない場合の約 0.14 倍以下になっていることから, 計算でもパッケージング することで振動の影響が抑えられることが確かめられ る.

4. パッケージングを用いた温度センシング

次に, パッケージングされた共振器を用いて温度セン シングを行った結果について紹介する。パッケージング した素子をペルチェ素子上に置き，実測值を得るために プローブ型の温度計 (測定誤差 $0.05{ }^{\circ} \mathrm{C}$, 分解能 $0.1{ }^{\circ} \mathrm{C}$ )を 用いた，各温度における透過スペクトルを測定し，共振 波長シフトを測ることによって得られた温度と共振波長 シフトの関係をFig. 7に示す. Fig. 7に示した近似直線か ら，作製したパッケージングによる温度の感度は $13.2 \mathrm{pm} /{ }^{\circ} \mathrm{C}$ と計算できる。これはシリカの熱光学定数及 び共振器サイズに依存する量であり，パッケージングさ

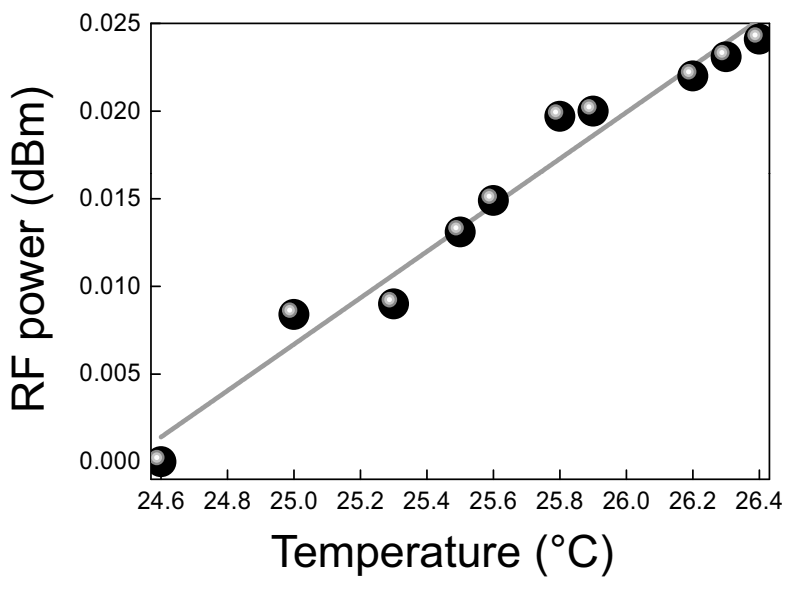

Fig. 7 Demonstration of temperature sensing. Resonant shift versus temperature of the packaged device. Solid line is the fitting.

れていないWGM共振器による温度センシングの感度は $5 \mathrm{pm} /{ }^{\circ} \mathrm{C}$ 程度と報告されている ${ }^{13)}$.

本センサは両端がシングルモードに接続された $\mathrm{mm} サ$ イズの極めて小さな素子なので，人が入ることが難しい 場所にインストールしておき光ファイバでネットワーク を組めば，リアルタイムでリモート温度センシングが可 能となるうえ，わずかな相対温度変化をいち早くとらえ ることができる多点同時計測ネットワークを組むことが できる。

\section{5. センシング応用に向けた流路内パッケージング}

最後に，気体・液体センシング応用に向け，流路内共 振器をパッケージングした結果について紹介する。共振 器を流路内にパッケージングした写真をFig 8に示す. また，Fig. 8のように作製した素子を用いて，純水を流 路に流した状態で透過スペクトルを測定した結果を Fig. 9に示す。液中測定においては液体の光吸収が $Q$ 值 を決める大きな要因となる。1 $1550 \mathrm{~nm}$ での水の吸収係数 は9.6 $\mathrm{cm}^{-1}$ と大きいことから高 $Q$ 值が得られないので,

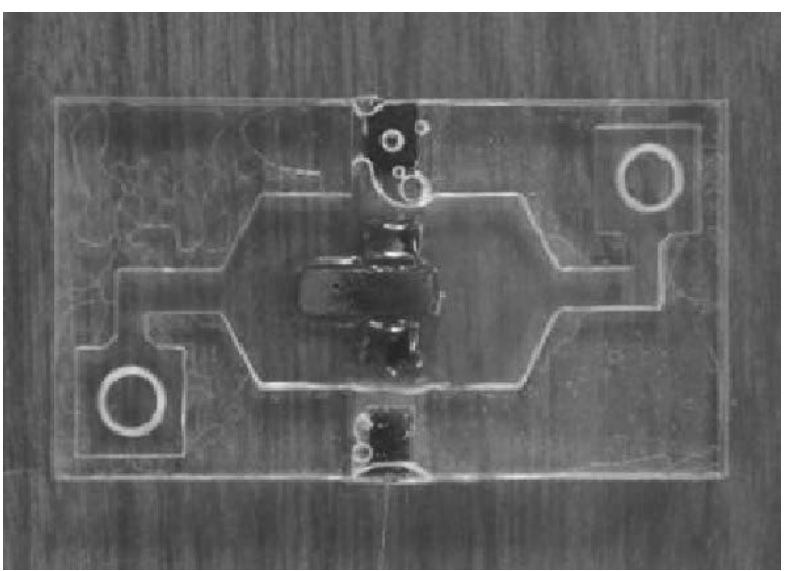

Fig. 8 Photograph of a packaged cavity integrated in a microfluidic channel. 


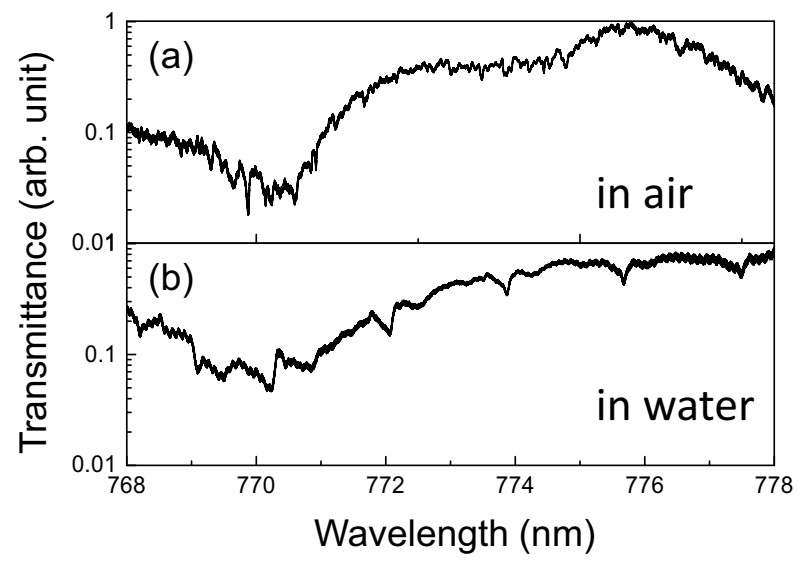

Fig. 9 Transmittance spectra of packaged cavity integrated with a microfluidic channel in the air (a) and in water (b).

本実験においては水の吸収係数が $0.025 \mathrm{~cm}^{-1}$ と小さい可 視〜近赤外領域の波長 $(760 〜 780 \mathrm{~nm})$ を用いた ${ }^{14)}$.

Fig. 9より，純水を流した状態でも共振が見られてお り, 共振器とテーパファイバが液中でも測定可能な状態 でパッケージングされていることが示された。また， Fig. 9より $Q$ 值を求めると空気中で $Q=1.7 \times 10^{6}$, 純水中 で $Q=1.6 \times 10^{4}$ となった， $Q$ 值が低下しているうえ, 空気 中に比べて液中でモード数が少なくなっているが, 空気 の屈折率が 1.00 , 純水の屈折率が $1.33, \mathrm{SiO}_{2}$ の屈折率が 1.44であることを考えると, 共振器中に閉じ込められる モードが少なくなり, 共振器の外に光が漏れ出す量が多 くなることは妥当だといえる。

しかし，流路に純水を流した際に共振が見えなくなる ことが多い等, ファイバの固定性を向上させることが課 題である.

\section{6. まとめ}

シリカトロイド共振器とテーパファイバを測定可能な 状態でパッケージングした，時間や振動に対する安定性 も評価した，パッケージングした素子には光の入出力用 のシングルモード光ファイバが1入力, 1 出力あり, その まま様々なセンシングに用いることができる。例えば,
我々は本論文で報告した温度センシング以外にも，高感

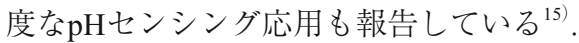

一方で, シリカトロイド共振器の持つ高 $Q$ 值を考える と $Q=1.7 \times 10^{6}$ は十分な值とは言えず, $Q$ 值の向上は今後 の課題としてあげられる。また，センシング応用に向 け，流路内のパッケージングも実現できたが，液体を流 してもファイバが移動しないように固定性を向上させる ことが課題である.

微小光共振器素子を用いると高感度な温度センシング が行えること自体は既知である。しかしながら，それを 実際にパッケージングした形態でデモンストレーション した例はこれまでに例がない，本報告は微小光共振器素 子をフィールドで利用できる形態でデモンストレーショ ンした世界初の成果である. 同素子の有用性を示す一つ の例として重要な成果として位置づけられる。

\section{参考文献}

1) D. K. Armani, T. J. Kippenberg, S. M. Spillane, and K. J. Vahala: Nature 421 (2003) 925.

2) T. J. Kippenberg, R. Holzwarth, and S. A. Diddams: Science 332 (2011) 555

3) A. M. Armani and K. J. Vahala: Opt. Lett. 31 (2006) 1896.

4) J. M. Ward and S. Nic Chormaic: Appl. Phys. B 100 (2010) 847.

5) F. Vollmer, D. Braun, A. Libchaber, M. Khoshsima, I. Teraoka, and S. Arnold: Appl. Phys. Lett. 80 (2002) 4057.

6) J. Zhu, Ș. K. Özdemir, L. He, D. Chen, and L. Yang: Opt. Express 19 (2011) 16195.

7) T. Lua, H. Leea, T. Chena, S. Herchakb, J. Kima, S. E. Frasera, R. C. Flagand, and K. Vahala: Proc. Nat. Acad. Sci. 108 (2011) 5976.

8) K. Scholten, X. Fan, and E. T. Zellers: Lab Chip 14 (2014) 3873.

9) T. Kato, W. Yoshiki, R. Suzuki, and T. Tanabe: Appl. Phys. Lett. 101 (2012) 121101.

10) R. Suzuki, T. Kato, T. Tetsumoto, and T. Tanabe: AIP Advances 5 (2015) 057127.

11) Y. Yan, C. Zou, S. Yan, F. Sun, Z. Ji, J. Liu, Y. Zhang, L. Wang, C. Xue, W. Zhang, Z. Han, and J. Xiong: Opt. Express 19 (2011) 5753.

12) F. Monifi, S. K. Özdemir, J. Friedlein, and L. Yang: IEEE Phot. Technol. Lett. 25 (2013) 1458.

13) C. H. Dong, L. He, Y. F. Xiao, V. R. Gaddam, S. K. Ozdemir, Z. F. Han, G. C. Guo, and L. Yang: Appl. Phys. Lett. 94 (2009) 231119.

14) W. M. Irvine and J. B. Pollack: Icarus 8 (1968) 324.

15) J. Nishimura, M. Kobayashi, R. Saito, and T. Tanabe: Appl. Opt. 54 (2015) 6391. 